\title{
Peran KKM 6.5 Composer's Collective bagi Mahasiswa Program Studi Penciptaan Musik FSP ISI Yogyakarta
}

\author{
Maria Octavia Rosiana Dewi \\ Program Studi S-1 Penciptaan Musik, FSP ISI Yoigyakarta; e-mail: vivi_pianist@yahoo.com.
}

\begin{abstract}
The KKM 6.5 Composers Collective is one of the student activities clubs at Music Department of the FSP ISI Yogyakarta, whose its members are music students whose their ellective study concentration is composition. This research aims to determine the program activities of the KKM 6.5 Composer's Collective, and its role in the development of student's composition as well as music composition study program during the years periods of 2014 to 2016. The results of this research indicate that all newly enrolled composition students were directed to participate in program activities of the KKM 6.5 Composer's Collective. There were annual programs that always scheduled and conducted regularly such as a concert of premiere compositions of new students, workshops, and composition classes. There is a reciprocal relationship between the KKM 6.5 Composer's Collective, who sometimes involved the alumni of Music Department who were active as composers, and the current students of Music Composition study program. From this student club's programs, composition students have gained broader insight and experiences so that are beneficial as a support for their academic learning process
\end{abstract}

Keywords: KKM 6.5 Composers Collective, music composition, student activity club

\begin{abstract}
Abstrak
KKM 6.5 Composer Colective adalah salah satu klub kegiatan kemahasiswaan di Departemen Musik FSP ISI Yogyakarta, yang anggotanya adalah mahasiswa musik yang konsentrasi studi elektifnya adalah komposisi. Penelitian ini bertujuan untuk mengetahui kegiatan program KKM 6.5 Composer Colective, serta perannya dalam pengembangan komposisi mahasiswa serta program studi komposisi musik selama periode tahun 2014 sampai 2016. Hasil penelitian ini menunjukkan bahwa semua mahasiswa komposisi yang baru masuk diarahkan untuk berpartisipasi dalam kegiatan program KKM 6.5 Composer Colective. Ada program tahunan yang selalu dijadwalkan dan dilakukan secara teratur seperti konser komposisi perdana mahasiswa baru, lokakarya, dan kelas komposisi. Ada hubungan timbal balik antara KKM 6.5 Composer's Collective, yang terkadang melibatkan alumni Jurusan Musik yang menjadi komposer aktif, dan mahasiswa program studi Komposisi Musik saat ini. Dari program klub mahasiswa ini, para mahasiswa komposisi telah mendapatkan wawasan dan pengalaman yang luas sehingga bermanfaat sebagai dukungan untuk proses belajar akademik mereka.
\end{abstract}

Kata kunci: KKM 6.5 Composers Collective, komposisi musik, kelompok kegiatan mahasiswa

\section{Pengantar}

KKM 6,5 Composers Collective merupakan salah satu Kelompok Kegiatan Mahasiswa (KKM) yang didirikan pada tahun 2008 oleh mahasiswa Minat Utama Komposisi dari Program Studi S1 Seni Musik di Jurusan Musik, Fakultas Seni Pertunjukan (FSP), In- stitut Seni Indonesia Yogyakarta (ISI Yogyakarta). Saat itu KKM 6,5 Composers Collective tergabung sebagai salah satu dari berberapa KKM musik yang lain, yang secara organisasi berada di bawah koordinasi Himpunan Mahasiswa Jurusan (HMJ) Musik. Dalam lingkup, HIMA Musik berada di bawah 
bawah koordinasi Badan Eksekutif Mahasiswa (BEM), FSP ISI Yogyakarta.

Pada tahun 2014, bersama dengan ketiga Minat Utama (MU) yang lainnya pada kurikulum S1 Seni Musik di Jurusan Musik FSP ISI Yogyakarta, yaitu Musik Pendidikan, Musik Pertunjukan, dan Pop-Jazz, usulan pengembangan MU Komposisi Musik menjadi program studi S1 Penciptaan Musik terwujud dengan terbitnya mandat Direktur Jenderal Pendidikan Tinggi tentang pembukaan ketiga program studi baru musik (Surat Mandat Dirjen Dikti No.674/E. E2/DT/2014). Setelah ditindaklanjuti oleh penerbitan SK Rektor ISI Yogyakarta tentang pendirian program studi baru, setahun kemudian Program Studi Penciptaan Musik akhirnya mendapatkan ijin pelaksanaan program studi berdasarkan SK Dirjen Dikti No. 674/ E.E2/ DT/ 2014 dan No. 30/ M/ Kp/ III/ 2015). Sebagai program studi yang baru, mahasiswa dari program studi tersebut belum memiliki wadah kegiatan yang resmi, oleh karena itu, kegiatan mahasiswa Program Studi Penciptaan Musik diikutsertakan dalam kegiatan kemahasiswaan KKM 6,5 Composers Collective.

Sebagai kelompok kegiatan mahasiswa yang memiliki konsentrasi pada bidang komposisi musik, KKM 6,5 Composers Collective memiliki berbagai program kegiatan. Diantaranya adalah kegiatan workshop atau pelatihan bidang penciptaan musik dan juga pergelaran atau konser hasil karya komposisi musik dari mahasiswa, khususnya yang memiliki minat utama komposisi musik. Pada program kegiatan KKM 6,5 Composers Collective tersebut, mahasiswa Program Studi Penciptaan Musik ikut ambil bagian dan berperan di dalamnya

Program kegiatan KKM 6,5 Composers Collective menjadi suatu ajang atau tempat berkreasi bagi mahasiswa Program Studi Penciptaan Musik. Kegiatan tersebut juga sangat membantu mahasiswa Program Studi Penciptaan Musik dalam menimba pengala- man dan pengetahuan di luar akademik untuk pengembangan kemampuan dan kreativitas mereka dalam berkarya di bidang komposisi musik. Kemampuan dan kreativitas tersebut nantinya diharapkan akan dapat digunakan dalam pengembangan kemampuan akademik, terutama dalam bidang kekaryaan atau penciptaan musik yang sedang mereka geluti.

Latar belakang tersebut diatas yang membuat peneliti tertarik untuk meneliti tentang peranan organisasi Kelompok Kegiatan Mahasiswa (KKM) 6,5 Composers Collective bagi mahasiswa Program Studi Penciptaan Musik Institut Seni Indonesia Yogyakarta. Ketertarikan tersebut membuat peneliti ingin meneliti lebih jauh mengenai program dan kegiatan Kelompok Kegiatan Mahasiswa (KKM) 6,5 Composers Collective yang dilakukan oleh KKM 6,5 Composers Collective dalam pengembangan bidang komposisi musik dari tahun 2014-2016, serta peranan dari program dan kegiatan tersebut bagi pengembangan kreativitas berkarya mahasiswa Program Studi Penciptaan Musik.

Kreativitas musik adalah kemampuan untuk menghasilkan suatu karya atau dengan kata lain menjadi kreatif pada berbagai macam bidang di dalam musik, seperti dalam bentuk komposisi, improvisasi, aransemen atau pengaturan ulang, remix, rekaman atau bahkan cara mendengarkan karya musik tertentu. (Mazzola, Park \& Thalman, 2011:145)

Kreativitas memiliki ruang lingkup topik yang luas dalam berbagai bidang, baik pada tingkat individu maupun sosial. Pada tingkat individu, kreativitas adalah relevan, misalnya ketika seseorang memecahkan masalah dalam pekerjaan dan dalam kehidupan sehari-hari. Pada tingkat sosial, kreativitas dapat menyebabkan temuan ilmiah baru, gerakan baru dan penemuan baru. (Stenberg dan Lubart,1999:3)

Unsur-unsur dari kreativitas dapat dijabarkan ke dalam empat hal yaitu: Proses, Produk, Person (pribadi) serta Place (tempat). 
Proses adalah hal yang paling penting dalam unsur ini. Produk berkaitan dengan hasil dari proses kreatif berbentuk karya komposisi musik. Person (pribadi) adalah sebagai subyek utama dalam proses kreatif. Place (tempat), berhubungan dengan lingkungan atau tempat dimana pribadi tersebut berada. Menurut Galton, James, Freud, dan Maslow, lingkungan memiliki pengaruh terbesar pada potensi kreatif seseorang. (Mazzola, Park \& Thalman, 2011:141-142)

Hasil dari sebuah kreativitas musik adalah sebuah komposisi musik, yang dapat didefinisikan sebagai sebuah proses berlangsungnya cara kerja dan terwujudnya suatu karya musik. Karya musik sebagai buah pikiran, merupakan bentuk ekspresi diri yang terwujud karena proses kerja pengaturan, penyusunan proporsi, konstruksi, bentuk dan sebagainya. (Hardjana, 2003:79)

Dalam proses kreativitas tidak hanya meliputi aspek kognitif, tetapi juga kualitas pribadi, seperti karakteristik sosial dan emosional, keluarga dan hal-hal pendidikan yang mungkin relevan, fitur kritis dari berbagai bidang, domain, isu-isu kontekstual sosial budaya dan peristiwa sejarah serta aspek-aspek lainnya. (Feldman, 1999: 171-172) Menurut Woodman, Sawyer, dan Griffin, suatu tindakan kreatif mungkin akan cukup rumit ketika dilakukan secara individual saja, namun dinamisme yang tinggi akan dicapai ketika individu mencoba untuk membuat suatu tindakan kreatif dalam suatu sistem organisasi. (Ericsson dan Moxley; Mumford, 2011:141).

Dalam kelompok organisasi atau komunitas bidang komposisi musik, peranan anggota sangat penting. Setiap anggota dalam komunitas tersebut mungkin harus dapat berperan sebagai komposer, kolaborator, kritikus, pemain, penonton, dan penata artistik. Peranan tersebut dapat menambah pengalaman dan wawasan anggota kelompok sebagai bahan pertimbangan proses kreatif dengan berbagai sudut pandang yang berbeda. (Kaschub and Smith, 2009:103) Anggota yang berpartisipasi dalam komunitas tersebut kemudian akan tertarik dalam membuat komposisi musik. Meskipun mereka belajar banyak dari para musisi di sekitar mereka, namun mereka juga dituntut untukmembuat karya musik mereka sendiri.

Komposer dalam proses kreatifnya dapat tumbuh dan berkembang melalui paparan kritik yang membangun. Belajar menerima kritik adalah bagian penting dari pengalaman masing-masing anggota dalam komunitas. Komposer perlu belajar untuk mempertimbangkan bagaimana reaksi penonton terhadap karya-karya mereka, demikian pula komentar dan tanggapan dari rekan mereka mengenai bagaimana musik yang mereka dengar. Belajar untuk menawarkan kritik yang membangun dan berguna dari komposer lain merupakan keterampilan penting yang dapat memberikan kontribusi besar terhadap pembentukan kepercayaan antara anggota dan masyarakat secara luas. (Kaschub and Smith, 2009:104)

Penelitian ini dilakukan dengan tujuan selain untuk menjawab segala permasalahan yang telah dirumuskan, namun diharapkan dapat memberikan wawasan bahwa proses kreativitas bidang komposisi musik yang tidak hanya didapat secara individu namun dapat diperoleh dalam suatu organisasi bidang yang sama, sehingga pengetahuan dan pengalaman akan berkembang lebih luas.

Dalam penelitian ini menggunakan metode penelitian secara kualitatif dengan pendekatan multi disiplin baik secara historis, sosiologis maupun musikologis. Pendekatan tersebut juga berkaitan dengan fenomena kualitatif, yaitu, fenomena yang berkaitan dengan kualitas atau jenis. Misalnya, ketika kita tertarik menyelidiki alasan perilaku manusia, sebagai contoh mengapa orang berpikir atau melakukan hal-hal tertentu. (Khotari, 2004: 3) 


\section{Pembahasan}

\section{Sejarah Pendirian KKM 6,5 Compos- ers Collective}

Pada tahun 2008, minat utama komposisi musik secara resmi dimasukkan sebagai salah satu dari minat-minat utama kurikulum Program Studi S1 Seni Musik pada Jurusan Musik, FSP ISI Yogyakarta. Beberapa mahasiswa saat itu, diantaranya, Christanto Hadinata , Gatot Danar Sulistiyanto dan Tony Maryana, berinisiatif menghidupkan kelas komposisi di dalam kampus, dengan diawali konser sederhana mahasiswa minat utama komposisi angkatan pertama.

Agenda kegiatan tersebut diberi nama 6,5 Composers Collective Days, yang kemudian nama tersebut digunakan sebagai nama KKM mahasiswa minat komposisi yang baru pada saat itu. Ide nama 6,5 diambil dari nama jalan kampus ISI Yogyakarta, yaitu Jalan Parangtritis km 6,5 Yogyakarta. Nama Composers Collective memiliki arti persatuan para komposer musik. Logo yang digunakan berbentuk kurva angka 65 dengan gradasi biru yang mengandung arti seperti tetes bulir air yang menyimbolkan kehidupan. (wawancara dengan Christanto Hadinata tanggal 16 Oktober 2016).

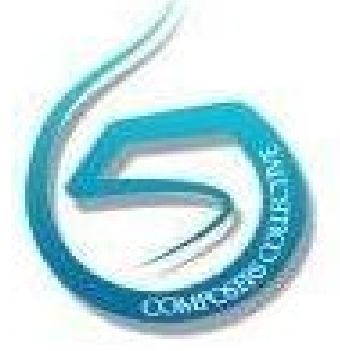

Iustrasi 1.

Logo 6,5 Composers Collective

Kegiatan tersebut kemudian berlanjut menjadi konser yang bertajuk festival tahunan dengan tema Art Music Young Composition yang berlangsung secara sukses pada tahun 2008 dan 2009. Tujuan dari festival tersebut adalah membuka kesempatan bagi siapapun yang berminat pada penciptaan musik dan tidak terbatas pada mahasiswa minat komposisi musik saja namun juga mengundang mahasiswa dari minat lain dan jurusan lain bahkan dari kampus lain diluar ISI Yogyakarta.

\section{Masa Kepengurusan}

Pada bulan Mei 2008, 6,5 Composer Collective secara resmi menjadi Kelompok Kegiatan Mahasiswa (KKM) yang masuk di dalam organisasi Himpunan Mahasiswa Jurusan (HMJ) Musik dan bernaung dibawah organisasi Badan Eksekutif Mahasiswa, Fakultas Seni Pertunjukan, Institut Seni Indonesia Yogyakarta.

Pada saat itu dipilih sebagai ketua KKM 6,5 Composer Collective yang pertama adalah Christanto Hadijaya selama tahun 2008-2009. Ketua 6,5 Composer Collective yang kedua adalah Gardika Gigih Pradipta (periode tahun 2009-2010). Sebagai ketua berikutnya adalah Rocky Irvano pada tahun 2010-2012. Periode kepengurusan yang berikutnya,yaitu pada tahun 2012-2013, ketua dijabat oleh Anastasia Hapsari dan dilanjutkan oleh Aldy Maulana di tahun 2013-2014. Pada awal tahun 2015, Septian Dwi Cahyo dipilih menjadi ketua 6,5 Composer Collective dengan masa jabatan hingga tahun 2016. Pada bulan Mei 2016, sebagai ketua KKM 6,5 Composer Collective periode tahun 2016 adalah Rafael Saktya Bramarsya, mahasiswa Prodi Penciptaan Musik, angkatan tahun 2014.

\section{Program-program kegiatan tahun 2014-2016}

Pada masa kepengurusan KKM 6,5 Composers Collective tahun 2014, programprogram yang diadakan tidak terlalu banyak, terutama pada saat diterimanya 10 orang mahasiswa Prodi Penciptaan Musik angkatan. Kegiatan yang cukup mendapat perhatian adalah sebuah acara yang merupakan kerjasama antara KKM 6,5 Composer Collective dengan mahasiswa komposisi musik dari Universitas Pelita Harapan Jakarta. Acara 
tersebut diadakan dalam bentuk workshop dan konser bersama di Lembaga Intitute Francaise deIndonesie (Lembaga Perancis Indonesia) Yogyakarta. Acara tersebut diadakan pada bulan Maret 2014, sehingga tidak melibatkan mahasiswa Prodi Penciptaan Musik yang pada saat itu belum terbentuk.

Pada masa kepengurusan KKM 6,5 Composers Collective 2015, terdapat beberapa program kegiatan yang banyak melibatkan mahasiswa Prodi Penciptaan Musik. Program kegiatan pada masa kepengurusan itu antara lain:

a. Diskusi bulan April 2015 dengan pembicara Gatot Danar Sulistyanto

b. Diskusi bulan Mei 2015 dengan pembicara Erie Setiawan

c. Diskusi bulan Juni 2015 dengan pembicara Arham Aryadi

d. Lokakarya \#1 di bulan Juni 2015 dengan narasumber Royke Bobby Koapaha, Chairul Slamet dan Gatot Danar Sulistyanto

e. Diskusi bulan Agustus 2015 dengan pembicara Patrick Gunawan Hartono

f. Lokakarya \#2 di bulan September 2015 dengan narasumber Vincent Mc Dermott dan Budi Ngurah

g. Konser 6,5 Composers Collective 2015 di bulan November 2015

h. Lokakarya \#3 di bulan Februari 2016 dengan narasumber Otto Sidharta dan Kristiyanto Christinus

Pada awal tahun 2016, pengurus

KKM 6,5 Composers Collective mengadakan diskusi mengenai pergantian pengurus dan sekaligus mengadakan pemilihan ketua KKM 6,5 Composers Collective 2016. Dalam pemilihan tersebut menghasilkan kesepakatan sebagai ketua KKM 6,5 Composers Collective 2016 adalah Rafael Saktya Bramarsya, mahasiswa Prodi Penciptaan Musik angkatan tahun 2014. Pelantikan ketua KKM 6,5 Composers Collective 2016 dilaksanakan bersamaan dengan kegiatan konser peluncuran buku "The Composers Journey".
Buku tersebut berisi tulisan-tulisan yang memaparkan ide-ide pembuatan karya-karya musik dari beberapa anggota KKM 6,5 Composers Collective ditambah beberapa tulisan dari dosen dan narasumber.

Selama masa kepengurusan KKM 6,5 Composers Collective 2016, ketua dibantu oleh beberapa mahasiswa gabungan dari Jurusan Musik dan Prodi Penciptaan Musik. Pengurus terdiri dari mahasiswa Jurusan Musik dengan minat komposisi, angkatan terakhir (2013), mahasiswa Prodi Penciptaan Musik angkatan pertama (2015) dan beberapa mahasiswa Prodi Penciptaan Musik angkatan kedua (2015).

Beberapa kegiatan yang sudah dilakukan selama masa kepengurusan KKM 6,5 Composers Collective 2016 antara lain:

a. Workshop dalam rangka persiapan Konser Perdana mahasiswa baru angkatan 2016. Workshop tersebut diadakan selama 4 kali berturutturut dengan narasumber beberapa alumni mahasiswa dan alumni pengurus, yaitu :

- Aldy Maulana, dengan materi tentang Kesadaran Materi Musikal, pada tanggal 14 September 2016

- Septian Dwi Cahyo, dengan materi tentang Alur Pembuatan Karya , pada tanggal 20 September 2016

- Gardika Gigih Pradipta, dengan materi tentang Pembuatan Musik Instan, pada tanggal 27 September 2016

- Vishnu Satya Graha, dengan materi tentang Sharing Karya, pada tanggal 4 Oktober 2016

b. Pada tanggal 14-16 Oktober 2016, KKM 6,5 Composers Collective 2016 ikut berpartisipasi sebagai media partner dalam acara festival komposisi musik bertaraf nasional yaitu October Meeting 
c. Pada tanggal 7 November 2016, mengadakan Konser Perdana karya-karya musik para mahasiswa baru angkatan 2016, yang merupakan hasil dari workshop yang sudah dilakukan 4 kali berturut-turut sebelumnya.

d. Pada tanggal 11 November 2016, diadakan diskusi bersama Septian Dwi Cahyo dengan materi Teknis Permainan Harpa.

\section{Pengaruh alumni dalam program kegiatan}

Alumni jurusan musik dengan minta utama komposisi musik yang pernah ikut bergabung dalam KKM 6,5 Composers Collective masih memberikan atensi atau perhatian kepada program kegiatan yang dilaksanakan oleh KKM tersebut hingga kini. Atensi secara langsung diberikan dengan cara membagikan pengalaman baik dalam pekerjaan yang mereka lakukan maupun dalam bidang kekaryaan yang pernah mereka ciptakan, melalui workshop maupun pelatihan yang dirancang dalam program kegiatan KKM 6,5 Composers Collective. Atensi tidak langsung yang diberikan adalah dengan memberikan masukan dalam suatu diskusi melalui media sosial. Pengaruh secara tidak langsung juga didapat dari hasil karya yang telah dibuat oleh alumni dan karya tersebut mendapat pengakuan dari khalayak luas.

Beberapa alumni Jurusan Musik yang pernah ikut bergabung dan berperan besar, baik sebagai pelopor maupun penggerak dalam kegiatan KKM 6,5 Composer Collective tersebut, masih sangat aktif berkarya hingga saat ini. Bahkan beberapa karya mereka mendapat apresiasi yang baik dari khalayak atau masyarakat luas, baik secara nasional maupun internasional, seperti yang diraih oleh Gatot Danar Gatot Danar Sulistyanto (alumni angkatan tahun 2000) dari Ford Foundation-IIEF \& Asia-New Zealand Foundation, pada Juni 2008 , Prince Claus Foundation, pada Juni 2009 dan Kelola Foundation, pada September 2012. (gatotdanars.yolasite.com)

Apresiasi serupa juga diraih oleh Gardika Gigih Pradipta (alumni angkatan tahun 2007), antara lain mendapat peringkat kedua di Sfogato Art Festival, Krakow-Polandia pada bulan Oktober 2011, dengan sebuah karya ringtone. Hibah dari Kelola Foundation, Jakarta untuk proyek karya inovatif, pada bulan April 2012, (gardikagigih.blogspot.co.id) nominasi karya musik film pendek dalam ajang FFI di Melbourne, dan juga mendapat penghargaan film terbaik favorit pemirsa dalam film berjudul "Lemantun" dalam ajang XXI Short Film Festival. Penghargaan selanjutnya adalah musik film dokumenter pendek terbaik dalam ajang Festival Film Dokumenter 2015 dan juga nominasi musik film pendek terbaik dalam ajang Festival Film Indonesia 2015. Yang terbaru, Gardika Gigih Pradipta mendapatkan penghargaan bergengsi yaitu Anugerah Telkomsel 2016 sebagai komposer inspiratif. (vip.kompas.com/telkomsel)

Alumni selanjutnya adalah Vishnu Satyagraha (alumni angkatan tahun 2007) yang cukup diakui eksistensinya dalam karya musik seni maupun industri, seperti dalam bidang musik film pendek, iklan komersil maupun musik untuk program televisi. Selain itu juga pernah mendapat beberapa penghargaan, antara lain dari Lomba Mars BMKG yang diadakan BMKG Nasional Indonesia, pada tahun 2011, sebagai juara I, Lomba Cipta Lagu Ekaristi yang diadakan oleh Keuskupan Agung Jakarta, pada tahun 2014, sebagai Karya Nyanyian Penutup Terbaik, Sayembara Jingle Cagar Budaya, yang diadakan Kementrian Pendidikan dan Kebudayaan, pada tahun 2015, sebagai juara I. Lomba Cipta Lagu PAUD yang diadakan Dirjen PAUD Kemendikbud, pada tahun 2016 sebagai juara harapan, dan Lomba Jingle Grhatama Pustaka yang diadakan BPAD DIY, pada tahun 2016, sebagai juara III.

Seorang alumni angkatan tahun 2010, bernama Aldy Maulana juga memiliki peran 
dalam pengembangan kegiatan KKM 6,5 Composers Collective. Beberapa penghargaan yang pernah diraih, antara lain: sebagai Finalis 11 komposisi terbaik dalam Festival Gaudeamus Music week, Basklarinet Festijn di Utrecht, Belanda, pada tahun 2015, dan mendapatkan Spesial Prize dan Commision work pada acara kompetisi komposisi October Meeting, untuk Cellosonata Amsterdam yang akan dimainkan oleh Cellist Doris Hohscied dan Franz Van Ruth untuk performance selanjutnya.

\section{Keterlibatan mahasiswa Prodi Pen- ciptaan Musik}

Pada masa awal kuliah, mahasiswa Prodi Penciptaan Musik angkatan 2014 tidak segera langsung bergabung ikut dengan KKM 6,5 Composers Collective dikarenakan adanya beberapa hal yang menjadi hambatan dan kendala pada kepengurusan tahun 2014. Hal tersebut juga yang menyebabkan program kegiatan pada saat itu tidak terlalu banyak. Baru kemudian pada masa kepengurusan di awal tahun 2015, seluruh mahasiswa prodi Penciptaan Musik diajak turut serta bergabung dalam program kegiatan yang diadakan oleh KKM 6,5 Composers Collective. Keterlibatan mahasiswa Prodi Penciptaan Musik pertama kali dalam acara diskusi bulan April 2015, kemudian berlanjut dalam program kegiatan berikutnya sampai masa kepengurusan KKM 6,5 Composers Collective 2015 berakhir.

Dalam kepengurusan KKM 6,5 Composers Collective 2016, peran mahasiswa Prodi Penciptaan Musik sangat kuat dengan terpilihnya salah satu mahasiswa Prodi Penciptaan Musik angkatan 2014 sebagai ketua. Hal tersebut juga dikarenakan akan berakhirnya minat utama Komposisi Musik di Jurusan Musik dan mahasiswa Jurusan Musik yang ikut tergabung dalam KKM 6,5 Composers Collective 2016 sangat sedikit, sehingga keterlibatan mahasiswa Prodi Penciptaan Musik juga memiliki manfaat yang sangat besar. Keterlibatan mahasiswa baru dalam Konser Perdana 2016 juga sangat memberikan warna dalam kepengurusan KKM 6,5 Composers Collective 2016.

\section{Hasil Penelitian}

Mahasiswa Prodi Penciptaan Musik terdiri dari tiga angkatan, yaitu angkatan tahun 2014, tahun 2015 dan tahun 2016. Mahasiswa Prodi Penciptaan Musik angkatan tahun 2014 berjumlah 10 orang, angkatan tahun 2015 berjumlah 25 orang dan angkatan tahun 2016 berjumlah 30 orang. Keseluruhan mahasiswa Prodi Penciptaan Musik adalah berjumlah 65 orang. Jumlah tersebut relatif cukup bagi suatu penyelenggaraan Program Studi yang baru.

Proses dalam penelitian ini dilakukan dengan salah satu motode pemberian kuesioner kepada sampel yang dipilih, yaitu mahasiswa Prodi Penciptaan Musik dari angkatan 2014-2016. Jumlah sampel yang dipilih adalah maksimal $60 \%$ dari setiap angkatan. Setelah diadakan cara pemilihan sampel secara acak (random) dari setiap angkatan, maka kemudian kuesioner tersebut diberikan dengan berisi beberapa pertanyaan mengenai pendapat mereka tentang KKM 6,5 Composers Collective.

a. Dalam proses analisis hasil kuesioner, dipilih jawaban pertanyan yang paling banyak dijawab oleh sampel. Berikut adalah daftar pertanyaan dalam kuesioner dan hasil dari jawaban terbanyak pada kuesioner tersebut: Pertama kali mengenal KKM 6,5 Composer Collective:

- Pada saat PPAK.

- Saat mahasiswa Prodi Penciptaan Musik dikumpulkan oleh pengurus KKM.

b. Kesan pertama kali menngenal KKM 6,5 Composer Collective:

- Menarik, sehingga penasaran dan ingin bergabung dengan kegiatan KKM. 
- Bermanfaat untuk kuliah dan kemajuan anggota KKM.

- Ingin membuat karya sebanyakbanyaknya.

c. Kesan setelah mengenal sejarah berdirinya 6,5 CC adalah mereka termotivasi sebagai penerus.

d. Pendapat tentang program-program kegiatan 6,5 CC yang sudah berjalan:

- Dapat menambah wawasan tentang dasar komposisi.

- Sebagai wadah berkarya.

- Membantu dalam mengerjakan tugas.

e. Pendapat tentang program-program kegiatan 6,5 CC yang akan datang ialah bahwa workshop dan lokakarya harus tetap berjalan.

f. Pendapat responden tentang pengarahan langsung untuk ikut dalam kegiatan 6,5 CC:

- Setuju dan tidak keberatan bergabung dengan KKM.

- Setuju karena dapat menjadi wadah dalam berkarya.

g. Kesan terhadap kepengurusan periode lalu? Jawab: Baik

h. Kesan terhadap kepengurusan saat ini:

- Baik karena mengadakan pertemuan sehingga dapat berbagi pengetahuan dan sharing setiap minggu.

- Terbuka.

- Programnya inovatif.

- Baik karena selalu berdiskusi dengan kepengurusan yang lalu.

i. Manfaat yang didapat setelah ikut dalam program kegiatan 6,5 CC:

- Mengerti sistematika dalam membuat komposisi.

- Mendapat ilmu dan pengalaman

- Menambah relasi.

- Workshop komposisi sangat bermanfaat.

- Mengetahui aspek-aspek dalam membuat karya.
- Bisa sharing.

- Mendapat lingkungan bermusik yang baik.

- Bisa mengenal senior, alumni dan orang-orang yang berkecimpung di dunia komposisi.

- Meningkatkan kualitas musikalitas.

- Mendapat tempat untuk mempresentasikan karya.

- Mendapat motivasi dari senior, alumni.

- Bertanggung jawab terhadap karya.

- Mengenal genre musik baru.

j. Perkembangan kemampuan bermusik terutama dalam bidang komposisi setelah mengikuti program 6,5 CC:

- Mengetahui tentang cara membuat komposisi.

- Terbuka terhadap dunia komposisi yang rumit.

- Referensi bertambah.

- Mengetahui bahwa dalam membuat komposisi musik harus memiliki ide yang kuat.

- Bisa mempertanggungjawabkan karya.

- Lebih lancar dalam menuliskan program komputer Sibelius untuk kepentingan penulisian notasi.

k. Apakah pengalaman mengikuti program kegiatan 6,5 CC turut berpengaruh dalam proses pembuatan karya komposisi musik yang dibuat? Jawab: Ya, dengan alasan:

- Menambah wawasan berkarya.

- Berusaha jujur dalam berkarya.

- Dapat mengetahui aspek-aspek pembuatan komposisi.

- Makin bebas dalam berkarya.

- Komposisi yang dibuat menjadi lebih baik.

- Lebih menghargai karya orang lain. 
- Karya yang dibuat menjadi lebih bervariasi.

1. Pengaruh program kegiatan 6,5 CC bagi kelancaran mengikuti aktivitas perkuliahan atau akademik terutama mata kuliah Komposisi Musik:

- Menambah ilmu.

- Membantu dalam menulis karya.

- Membantu dalam mata kuliah solfegio, organologi, teori musik

- Lebih mengerti apa yang diajarkan di kelas.

- Teratasinya berbagai kesulitan yang dihadapi saat mengerjakan tugas kuliah komposisi musik.

- Bermanfaat dalam menyusun tulisan dalam bentuk artikel atau karya tulis tentang komposisi musik.

m. Apakah akan berniat selalu ikut aktif dalam kegiatan 6,5 CC selama masih menjadi mahasiswa Prodi Penciptaan Musik? Jawab: Ya, Alasan:

- Ingin mengeksplorasi ilmu.

- Ingin membina relasi.

- Karena sangat membantu dalam berkarya.

- Sebagai tempat penilaian karya.

n. Saran untuk 6,5 CC

- Membuat music camp.

- Workshop dengan komponis terkenal dan variasi kegiatan selain workshop.

- Meningkatkan program kerja.

- Belajar komposisi dari alam.

- Agar terbuka dengan aliran musik baru.

- Berkolaborasi dengan bidang-bidang komposisi non musik.

- Bekerjasama dengan Orkes Mahasiswa.

o. Memperluas jaringan Kritik untuk 6,5 CC:

- Bahasannya supaya lebih disederhanakan untuk memfasilitasi mahasiswa yang mungkin belum terlalu paham.
- Lebih melihat pada keberhasilan kepengurusan yang sebelumnya.

- Tidah hanya mengulas musik yang atonal namun perlu juga membahas musik tonal namun tidak meninggalkan unsur tradisi sehingga dapat bermanfaat bagi perkembangan musik di Indonesia.

- Membutuhkan dukungan dana untuk kegiatan.

\section{Penutup}

Sejak awal masuk, mahasiswa Prodi Penciptaan Musik sudah diarahkan untuk ikut serta dalam program kegiatan yang diadakan oleh KKM 6,5 Composer's Collective. Terdapat beberapa program yang selalu diagendakan dan dilaksanakan rutin setiap tahun dan hampir seluruh mahasiswa Prodi Penciptaan Musik ikut terlibat didalamnya, antara lain dalam kegiatan workshop dengan berbagai narasumber, konser perdana mahasiswa baru, event October Meeting 2016 dan juga diskusi mingguan. Program kegiatan KKM 6,5 Composer's Collective semakin banyak dan berjalan lancar, seiring dengan bertambahnya jumlah mahasiswa di Prodi Penciptaan Musik dan keterlibatan mereka di dalamnya. Dalam melaksanakan program kegiatan, terdapat hubungan timbal balik antara kegiatan KKM 6,5 Composer's Collective dengan mahasiswa Prodi Penciptaan Musik.

Terdapat dua hal yang berperan bagi mahasiswa Prodi Penciptaan Musik, yakni peran dari alumni dan juga peran dari program kegiatan kegiatan KKM 6,5 Composer's Collective. Peran alumni secara langsung dalam memberikan pengalaman dan wawasan secara langsung melalui kegiatan workshop yang diadakan oleh KKM 6,5 Composers Collective dan secara tidak langsung melalui hasil karya alumni yang dapat diterima dan mendapat penghargaan oleh khalayak luas baik dari dalam maupun luar negeri. Dari hasil kuesioner yang telah diisi oleh sampel sebagai media penelitian, dapat dilihat 
bahwa program kegiatan yang diadakan oleh KKM 6,5 Composer's Collective ternyata memberikan sumbangsih dan manfaat yang cukup besar bagi mahasiswa Prodi Penciptaan Musik, baik dalam proses pengembangan kreativitas berkarya secara pribadi maupun dalam proses kegiatan perkuliahan atau secara akademik.

\section{Referensi}

Ericsson, K. Anders; Moxley, Jerad H. 2012. "The Expert Performance Approach and Deliberate Practice: Some Potential Implications for Studying Creative Performance in Organization", dalam Mumford, Michael. D. (ed.), Handbook of Organizational Creativity. USA: Elsevier Inc.,

Feldman, David Henry. 1999. "The Development of Creativity", dalam Robert J. Sternberg (ed.). Handbook of Creativity. Cambridge: Cambrigde University Press.
Hardjana, Suka. 2003. Corat Coret Musik Kontemporer Dulu dan Kini. Jakarta: Masyarakat Seni Pertunjukan Indonesia (MSPI).

Kaschub, Michele; Smith, Janice. 2009. Minds on Music: Composition for Creative and Critical Thinking. USA: Rowman \& Littlefield Education.

Khotari, C.R. 2004. Research Methodology: Method and Techniques. New Dehli: New Age Internasional Limited Publisher.

Mazzola, Guerino; Park, Joomi; dan Thalmann, Florian. 2011. Musical Creativiy: Strategies and Tools in Composition and Improvisation. Berlin, Heidelberg: Springer-Verlag.

Sternberg, Robert J. dan Lubart, Todd I. 1999. "The Concept of Creativity: Prospek and Paradigms", dalam Robert J. Sternberg (ed.), Handbook of Creativity. Cambridge: Cambridge University Press. 